Original Article

\title{
Treatment with insecticide and fungicide on the physiological quality of lentil seeds
}

\author{
Tratamento com inseticida e fungicida na qualidade fisiológica de sementes de lentilha
}

\author{
J. Ruberta* (D), S. H. B. Dornelles ${ }^{\mathrm{a}}$ (D), U. R. Nunes ${ }^{\mathrm{b}}$ (D), N. T. Pedrolloc (i), M. Peripollib (i) and J. C. Cassol ${ }^{\mathrm{b}}$ (D) \\ aUniversidade Federal de Santa Maria - UFSM, Centro de Ciências Naturais e Exatas, Programa de Pós-graduação em Agrobiologia, Santa Maria, \\ RS, Brasil \\ bUniversidade Federal de Santa Maria -- UFSM, Centro de Ciências Rurais, Programa de Pós-graduação em Agronomia, Santa Maria, RS, Brasil \\ ‘Engenheiro Agrônomo - Externo, Júlio de Castilhos, RS, Brasil
}

\begin{abstract}
The low Brazilian productive index and the high demand have aroused interest in the cultivation of lentils, however the legume is little known and needs further studies. The objective of this study was to analyze and identify the effects of treatments with insecticides and fungicides on the physiological quality of lentil seeds, CA-1512 strain. The experiments were conducted in the seed laboratory in a completely randomized design with seven treatments and four replicates. Seed treatment with Thiophanate-methyl; Fluazinam ${ }^{\circledR}(180 \mathrm{ml})+$ Pyraclostrobin; $^{\circ}$ Thiophanate-methyl; Fipronil ${ }^{\circledR}(150 \mathrm{ml})$ promoted higher levels of germination under accelerated aging, lower number of abnormal seedlings and longer lengths of shoot and radicle for the emergence in paper. Treatment with Carboxin; Thiram ${ }^{\circledast}(250 \mathrm{ml})+$ Imidacloprid $^{\circledast}(150 \mathrm{ml})$ allowed a higher value in the first count of germination in sand, lower number of dead seeds under accelerated aging and longer root length, in the emergence in sand. Shoot length in the emergence in sand increased after seed treatment with Metalaxyl-M; Fludioxonil ${ }^{\circledast}(75 \mathrm{ml})+$ Pyraclostrobin; Thiophanate-methyl; Fipronil ${ }^{\circledR}(150 \mathrm{ml})$. Treatments with fungicides and insecticides considerably improved the physiological properties of the seeds, thus being able to guarantee greater phytosanitary qualities in the field, generating healthier seedlings and with protection against possible pests and diseases, and consequently guaranteeing greater productivity.
\end{abstract}

Keywords: emergence, seed treatment, Lens culinaris.

\begin{abstract}
Resumo
O baixo índice produtivo brasileiro e a alta demanda têm despertado o interesse no cultivo da lentilha, porém a leguminosa é pouco conhecida e necessita maiores estudos. Objetivou-se neste trabalho analisar e identificar tratamentos com inseticidas e fungicidas na qualidade fisiológica das sementes de lentilha, linhagem CA-1512. Os experimentos foram conduzidos no laboratório de sementes em delineamento inteiramente casualizado com sete tratamentos e quatro repetições. O tratamento de semente com Tiofanato-metílico; Fluazinam ${ }^{\circledR}(180 \mathrm{ml})$ + Piraclosrobina; Tiofanato-metílico; Fipronil ${ }^{\circledR}(150 \mathrm{ml})$ proporcionou índices mais elevados de germinação no envelhecimento acelerado, menor número de plântulas anormais e maior comprimento de parte aérea e radícula, na emergência em papel. O tratamento com Carboxina; Tiram ${ }^{\circledR}(250 \mathrm{ml})+$ Imidacloprido $\AA(150 \mathrm{ml})$ possibilitou maior índice na primeira contagem de germinação em areia, menor número de sementes mortas no envelhecimento acelerado e maior comprimento de raiz, na emergência em areia. Já o comprimento da parte aérea, na emergência em areia, aumentou com o tratamento de semente Metalaxil-M; Fludioxonil ${ }^{\circledR}(75 \mathrm{ml})+$ Piraclosrobina; Tiofanato-metílico; Fipronil ${ }^{\circledR}(150 \mathrm{ml})$. Os tratamentos com fungicidas e inseticidas melhoraram consideravelmente as propriedades fisiológicas das sementes, podendo assim, garantir maiores qualidades fitossanitárias à campo, gerando plântulas mais sadias e com proteção para possíveis pragas e doenças, e consequentemente garantindo maiores produtividades.
\end{abstract}

Palavras-chave: emergência, tratamento de semente, Lens culinaris.

\section{Introduction}

Lentil (Lens culinaris Medick) is an annual cycle legume, belonging to the Fabaceae family and is among the five most important legumes in the world, due to its high nutritional value (Nascimento et al., 2016). Lentil has approximately $40-50 \%$ carbohydrates, $20-30 \%$ proteins,
1\% fat (Correa and Poltronieri, 2016; Silva, 2016), fibers and amino compounds (Johnson et al., 2013).

In 2018, the world production of lentil was 6,375,732 tons (FAOSTAT, 2020). In Brazil, its production is virtually zero; in 2017, it was only 8 tons (IBGE, 2019), thus having high

*e-mail: jaine_rubert@hotmail.com

Received: December 15, 2020 - Accepted: March 29, 2021 
import demand. Production levels are low due to the scarcity of technical knowledge on the crop and research with cultivars adapted to the conditions of climate and soil (EMBRAPA, 2018).

To obtain high yield it is important to give special attention to the physiological quality of the seeds used. Thus, the use of certified seeds combined with the application of phytosanitary products is fundamental for their good performance in the field (Lemes et al., 2019). Since the planting of the crop, the action of pests and pathogens present in the soil can cause failures in its development; thus, preventive use of insecticides and fungicides in the treatment of seeds is an alternative to avoid losses.

Seed treatment is commonly performed with the combination of insecticides and fungicides, following standards and doses recommended by manufacturers (Carvalho and Nakagawa, 2012). Its aim is to protect seeds from the attack of pathogens and insects of the soil, ensuring a good initial establishment of seedlings and with better utilization of their production potential (Balardin et al., 2011). This technology may include the application of insecticides, fungicides, biological products, inoculants, biostimulants, nutrients, among others (Menten and Moraes, 2010; Carvalho and Nakagawa, 2012).

It is extremely important that physiological quality tests be efficient to monitor the evolution of seed deterioration, especially when the seeds are subjected to adverse conditions. The application of solutions based on mixtures of fungicides, insecticides and other compounds has shown satisfactory results in the physiological quality of seeds and yield of crops such as soybean (Bem et al., 2020; Almeida et al., 2014). However, little is known about the influence of seed treatment on the germination of lentil seedlings.

Due to the lack of works in the literature that approach with the culture of lentils and mainly, with regard to seed treatment, sought to evaluate the influence of insecticides and fungicides on the initial quality of seedlings, in order to guarantee an adequate and "protected" initial stand. Thus, the present study aimed to evaluate the effect of seed treatment with different combinations of insecticides and fungicides on the physiological quality of lentil seeds.

\section{Material and Methods}

The experiments were conducted in the Didactic and Seed Research Laboratory of the Federal University of Santa Maria, using lentil seeds of the CA-1512 strain, provided by the company $\mathrm{UPL}^{\circledR}$. The experimental design was completely randomized with seven treatments, namely: (C): T1control; T2- Carboxin; Thiram ${ }^{\circledR}(250 \mathrm{ml})+$ Imidacloprid $^{\circledR}$ $(150 \mathrm{ml})$; T3- Carboxin; Thiram ${ }^{\circledR}(300 \mathrm{ml})+$ Imidacloprid $^{\circledR}$ $(150 \mathrm{ml})$; T4- Metalaxyl-M; Fludioxonil ${ }^{\circledR}(75 \mathrm{ml})+$ Pyraclostrobin; Thiophanate-methyl; Fipronil ${ }^{\circledR}(150 \mathrm{ml})$; T5- Metalaxyl-M; Fludioxonil ${ }^{\circledR}(100 \mathrm{ml})+$ Pyraclostrobin; Thiophanate-methyl; Fipronil ${ }^{\circledR}(150 \mathrm{ml})$; T6- Thiophanatemethyl; Fluazinam ${ }^{\circledast}(145 \mathrm{ml})+$ Pyraclostrobin; Thiophanatemethyl; Fipronil ${ }^{\circledR}(150 \mathrm{ml})$ and T7- Thiophanate-methyl;
Fluazinam $^{\circledR}(180 \mathrm{ml})+$ Pyraclostrobin; Thiophanate-methyl; Fipronil $^{\circledR}(150 \mathrm{ml})$, with four replicates.

Seed treatment was carried out in plastic packages with a capacity of two liters, using 500 grams of seeds per package. The volume of solution used was $600 \mathrm{~mL}$ $100 \mathrm{~kg}^{-1}$ of seeds and it was completed with distilled water. Seeds were mixed with the solution in $2 \mathrm{~kg}$ plastic bags and stirred to ensure uniformity of the treatments on the seeds (Dan et al., 2010). The tests were installed after the application of the treatments.

The evaluations were based on the first count of germination, accelerated aging test, percentage of abnormal seedlings, numbers of dead and hard seeds, emergence in sand and shoot and root lengths, which are the most common variables to determine the germination and vigor of seed lots (Amaro et al., 2015).

\subsection{Evaluation of seed physiological quality}

The physiological quality of the seeds, in paper, was evaluated by means of the first count of germination, germination percentage and number of abnormal seedlings. The tests were conducted with four replicates of 50 seeds per treatment distributed on two sheets of Germitest ${ }^{\circledR}$ paper moistened with a volume of distilled water equivalent to 2.5 times the weight of the dry paper (Brasil, 2009). The rolls were placed in plastic bags and put into a Biochemical Oxygen Demand (B.O.D.) germination chamber with controlled temperature at $20^{\circ} \mathrm{C}$ and with continuous lighting. First count of germination was performed in conjunction with the germination test, determining the percentage of abnormal seedlings five days after the beginning of the experiment (Brasil, 2009). The results were expressed as germination percentage at the first and last count.

The accelerated aging test was conducted using four subsamples of 50 seeds per treatment, which were arranged on stainless steel screen, placed inside plastic boxes (gerbox type), containing $40 \mathrm{~mL}$ of distilled water (Krzyzanowski et al., 2014). Subsequently, the boxes were taken to a water jacketed incubator (3015 model, VWR BRAND, USA), regulated at $41 \pm 1{ }^{\circ} \mathrm{C}$, and kept for $24 \mathrm{~h}$ (Marcos Filho, 1999). After this period, the seeds were subjected to the germination test, with evaluation of the percentage of abnormal seedlings on the fifth day after the installation of the test (Brasil, 2009).

\subsection{Evaluation of seed performance in sand}

Seed emergence in sand was evaluated by means of first count of germination, germination percentage, numbers of dead and hard seeds, percentage of abnormal seedlings, and radicle and shoot lengths. Twenty-five seeds were used per repetition of each treatment. The sand was sterilized in a forced air oven at $75{ }^{\circ} \mathrm{C}$ for 24 hours and was then sifted and arranged in trays (32 cm x $28 \mathrm{~cm} \times 10 \mathrm{~cm}$ ), totaling 4.5 kilograms per tray. The seeds were arranged in lines at $4 \mathrm{~cm}$ depth and covered with a thin layer of sand, according to the methodology described by Brasil (2009).

For radicle and shoot lengths, the measurements were performed with a digital caliper (BL100174BL model), using 40 seedlings per treatment. Root length was measured 
from the epicotyl to the tip of the longest primary root, while shoot length was measured from the base of the epicotyl of the seedlings to the tip of the primary leaves.

The experimental data were subjected to analysis of variance (ANOVA) and to Tukey test to group the means at $\mathrm{p} \leq 0.05$, using the statistical program Sisvar ${ }^{\circledR} 5.3$ (Ferreira, 2011).

\section{Results and Discussion}

Significant differences were observed in accelerated aging and first count of germination in paper and in sand (Table 1).

\subsection{Evaluation of seed physiological quality}

In relation to the accelerated aging test (Table 1$)$, the treatments T2 (Carboxin; Thiram ${ }^{\circledR}(250 \mathrm{ml})+$ Imidacloprid $^{\circledR}$ $(150 \mathrm{ml})$ ) and T7 (Thiophanate-methyl; Fluazinam ${ }^{\circledR}(180 \mathrm{ml})$ + Pyraclostrobin; Thiophanate-methyl; Fipronil ${ }^{\circledR}(150 \mathrm{ml})$ ) led to higher values of germination, equal to 49.5 and $47.5 \%$, respectively. The control treatment (T1) was the one with the worst performance, with $15.0 \%$. In first count of germination in paper, the treatment T4 (Metalaxyl-M; Fludioxonil $^{\circledR}(75 \mathrm{ml})+$ Pyraclostrobin; Thiophanate-methyl; Fipronil $^{\circledR}(150 \mathrm{ml})$ ) was statistically superior to the other treatments by the Tukey test at $5 \%$, obtaining the highest percentage of germination, with an average value of $75.5 \%$.

For the percentage of germination in paper, no significant influence was observed as a function of the different treatments (Table 2). However, although there was no statistical difference, it is possible to observe that the treatments T4 (Metalaxyl-M; Fludioxonil ${ }^{\circledR}$ $(75 \mathrm{ml})+$ Pyraclostrobin; Thiophanate-methyl; Fipronil ${ }^{\circledR}$ $(150 \mathrm{ml})$ ) and T7 (Thiophanate-methyl; Fluazinam ${ }^{\circledR}$
$(180 \mathrm{ml})+$ Pyraclostrobin; Thiophanate-methyl; Fipronil ${ }^{\circledR}$ $(150 \mathrm{ml}))$ led to adequate levels of germination, with values above $80 \%$, following the accepted standards for seed commercialization in Brazil (Brasil, 2003).

Regarding the variables abnormal seedlings and dead seeds, it can be seen that their percentages were similar between the means of the treatments, i.e., there were no statistical differences (Table 3). At the accelerated aging, a greater discrepancy of the treatments was observed when compared to the control (T1), which led to higher values of abnormal seedlings and dead seeds, $45 \%$ and $30.50 \%$, respectively (Table 3 ).

Regarding the variables radicle length and shoot length in paper (Table 4), it is possible to observe that the treatment T7 (Thiophanate-methyl; Fluazinam ${ }^{\circledR}(180 \mathrm{ml})$ + Pyraclostrobin; Thiophanate-methyl; Fipronil $\left.{ }^{\circledR}(150 \mathrm{ml})\right)$ obtained the highest values, among all treatments, for both variables. The treatments T5 (Metalaxyl-M; Fludioxonil ${ }^{\circledR}$ $(75 \mathrm{ml})+$ Pyraclostrobin; Thiophanate-methyl; Fipronil ${ }^{\circledR}$ $(150 \mathrm{ml}))$, T4 (Metalaxyl-M; Fludioxonil ${ }^{\circledR}(100 \mathrm{ml})+$ Pyraclostrobin; Thiophanate-methyl; Fipronil ${ }^{\circledR}(150 \mathrm{ml})$ ) and T6 (Thiophanate-methyl; Fluazinam ${ }^{\circledR}(145 \mathrm{ml})+$ Pyraclostrobin; Thiophanate-methyl; Fipronil ${ }^{\circledR}(150 \mathrm{ml})$ ) obtained the lowest values of root length, being inferior to the control. This may be related to the fact that these products may have caused an initial stress to the development of lentil seedlings. The treatment of seeds with T7 (Thiophanate-methyl; Fluazinam ${ }^{\circledR}(180 \mathrm{ml})+$ Pyraclostrobin; Thiophanate-methyl; Fipronil $\left.{ }^{\circledR}(150 \mathrm{ml})\right)$ proved to be more advantageous for shoot length and root length in paper because, besides not harming seeds, it promoted greater growth of radicle and shoot, which ensures a better establishment of the crop in the initial stage, with more vigorous seedlings, avoiding possible

Table 1. Averages of accelerated aging (AA) and first count of germination in paper and in sand of CA-1512 strain lentil seeds treated with different insecticides, fungicides and doses. Santa Maria, 2020.

\begin{tabular}{|c|c|c|c|c|c|c|}
\hline \multirow{3}{*}{ Treatments } & \multirow{2}{*}{\multicolumn{2}{|c|}{ Accelerated aging }} & \multicolumn{4}{|c|}{ First count of germination (\%) } \\
\hline & & & \multicolumn{2}{|c|}{ In paper } & \multicolumn{2}{|c|}{ In sand } \\
\hline & & Sd & & Sd & & Sd \\
\hline T1- Control & $15.0 \mathrm{~b}^{*}$ & 8.2 & $49.5 \mathrm{~b}$ & 7.9 & $22.0 \mathrm{~b}^{*}$ & 4.9 \\
\hline T2- Carboxina; $\operatorname{Tiram}^{\circledast}(250 \mathrm{ml})+$ Imidacloprido $^{\circledast}(150 \mathrm{ml})$ & $49.5 \mathrm{a}$ & 11.8 & $55.5 \mathrm{~b}$ & 4.7 & $58.0 \mathrm{a}$ & 13.0 \\
\hline T3- Carboxina; Tiram $^{\circledast}(300 \mathrm{ml})+$ Imidacloprido ${ }^{\oplus}(150 \mathrm{ml})$ & $26.5 \mathrm{~b}$ & 3.4 & $61.5 \mathrm{~b}$ & 8.3 & $43.0 \mathrm{a}$ & 7.7 \\
\hline $\begin{array}{l}\text { T4- Metalaxil-M; Fludioxonil }{ }^{\oplus}(75 \mathrm{ml})+\text { Piraclostrobina; } \\
\text { Tiofanato-metílico; Fipronil }{ }^{\circledR}(150 \mathrm{ml})\end{array}$ & $34.0 \mathrm{ab}$ & 5.7 & $75.5 \mathrm{a}$ & 6.1 & $44.0 \mathrm{a}$ & 7.1 \\
\hline $\begin{array}{l}\text { T5- Metalaxil-M; Fludioxonil }{ }^{\otimes}(100 \mathrm{ml})+\text { Piraclostrobina; } \\
\text { Tiofanato-metílico; Fipronil }{ }^{\circledR}(150 \mathrm{ml})\end{array}$ & $41.5 \mathrm{ab}$ & 8.2 & $57.5 \mathrm{~b}$ & 5.6 & $46.0 \mathrm{a}$ & 8.5 \\
\hline $\begin{array}{l}\text { T6- Tiofanato-metílico; Fluazinam }{ }^{\circledast}(145 \mathrm{ml})+ \\
\text { Piraclostrobina; Tiofanato-metílico; Fipronil }{ }^{\oplus}(150 \mathrm{ml})\end{array}$ & $40.5 \mathrm{ab}$ & 6.8 & $64.0 \mathrm{~b}$ & 6.4 & $50.5 \mathrm{a}$ & 8.1 \\
\hline $\begin{array}{l}\text { T7- Tiofanato-metílico; Fluazinam }{ }^{\oplus}(180 \mathrm{ml})+ \\
\text { Piraclostrobina; Tiofanato-metílico; Fipronil }{ }^{\oplus}(150 \mathrm{ml})\end{array}$ & $47.5 \mathrm{a}$ & 6.2 & $62.5 \mathrm{~b}$ & 7.0 & $57.5 \mathrm{a}$ & 7.7 \\
\hline Coefficient of variation (\%) & 20.9 & & 11.4 & & 18.4 & \\
\hline
\end{tabular}

*Means not followed by the same letter in the column were statistically different between cultivars in the Tukey test ( $\mathrm{p} \leq 0.05$ ); Sd: Standard deviation. 
Table 2. Averages of percentage of germination of CA-1512 strain lentil seeds in paper and in sand, and emergence in sand after germination tests. Santa Maria 2020.

\begin{tabular}{|c|c|c|c|c|c|c|}
\hline \multirow{3}{*}{ Treatments } & \multicolumn{4}{|c|}{ Percentage of germination (\%) } & \multirow{2}{*}{\multicolumn{2}{|c|}{$\begin{array}{l}\text { Emergence in } \\
\text { sand }(\%)\end{array}$}} \\
\hline & \multicolumn{2}{|c|}{ In paper } & \multicolumn{2}{|c|}{ In sand } & & \\
\hline & & Sd & & Sd & & Sd \\
\hline T1- Control & $76.5^{\mathrm{ns}}$ & 5.2 & 88.7 & 7.8 & $87.5 \mathrm{a}$ & 8.7 \\
\hline T2- Carboxina; Tiram ${ }^{\circledast}(250 \mathrm{ml})+$ Imidacloprido $^{\circledR}(150 \mathrm{ml})$ & 71.5 & 4.1 & 77.5 & 5.2 & $72.5 \mathrm{ab}$ & 6.0 \\
\hline T3- Carboxina; Tiram ${ }^{\oplus}(300 \mathrm{ml})+$ Imidacloprido $^{\oplus}(150 \mathrm{ml})$ & 75 & 3.8 & 73.7 & 4.5 & $56.25 \mathrm{~b}$ & 6.8 \\
\hline $\begin{array}{l}\text { T4- Metalaxil-M; Fludioxonil }{ }^{\oplus}(75 \mathrm{ml})+\text { Piraclostrobina; } \\
\text { Tiofanato-metílico; Fipronil }{ }^{\oplus}(150 \mathrm{ml})\end{array}$ & 84.5 & 5.8 & 92.5 & 3.9 & $91.25 \mathrm{a}$ & 4.5 \\
\hline $\begin{array}{l}\text { T5- Metalaxil-M; Fludioxonil }{ }^{\circledast}(100 \mathrm{ml})+\text { Piraclostrobina; } \\
\text { Tiofanato-metílico; Fipronil }^{\circledast}(150 \mathrm{ml})\end{array}$ & 71 & 4.5 & 92.5 & 3.8 & $90.0 \mathrm{a}$ & 6.1 \\
\hline $\begin{array}{l}\text { T6- Tiofanato-metílico; Fluazinam }{ }^{\circledast}(145 \mathrm{ml})+\text { Piraclostrobina; } \\
\text { Tiofanato-metílico; Fipronil }{ }^{\circledast}(150 \mathrm{ml})\end{array}$ & 76 & 3.1 & 85 & 4.1 & $82.5 \mathrm{a}$ & 5.5 \\
\hline $\begin{array}{l}\text { T7- Tiofanato-metílico; Fluazinam }{ }^{\otimes}(180 \mathrm{ml})+\text { Piraclostrobina; } \\
\text { Tiofanato-metílico; Fipronil }{ }^{\circledast}(150 \mathrm{ml})\end{array}$ & 80 & 5.3 & 90 & 5.3 & $90.0 \mathrm{a}$ & 3.3 \\
\hline Coefficient of variation (\%) & 9.5 & & 10.0 & & 12.6 & \\
\hline
\end{tabular}

${ }^{*}$ Means not followed by the same letter in the column were statistically different between cultivars in the Tukey test ( $\left.\mathrm{p} \leq 0.05\right)$; ns: not significant; Sd: Standard deviation.

Table 3. Averages of abnormal seedlings and dead seeds in the emergence in paper and accelerated aging (AA) of CA-1512 strain lentil seeds. Santa Maria, 2020.

\begin{tabular}{|c|c|c|c|c|c|c|c|c|}
\hline \multirow{3}{*}{ Treatments } & \multicolumn{4}{|c|}{ Abnormal seedlings (\%) } & \multicolumn{4}{|c|}{ Dead seeds (\%) } \\
\hline & \multicolumn{2}{|c|}{ In paper } & \multicolumn{2}{|c|}{ AA } & \multicolumn{2}{|c|}{ In paper } & \multicolumn{2}{|c|}{ AA } \\
\hline & & Sd & & Sd & & Sd & & Sd \\
\hline T1- Control & $16^{\mathrm{ns}}$ & 3.3 & $45.0 \mathrm{a}^{*}$ & 5.0 & 7.5 & 1.4 & $30.5 \mathrm{a}$ & 9.0 \\
\hline $\begin{array}{l}\text { T2- Carboxina; Tiram } \\
\text { Imidacloprido }^{\circledast}(250 \mathrm{ml})+ \\
(150 \mathrm{ml})\end{array}$ & 19.5 & 5.1 & $29.0 \mathrm{~b}$ & 6.2 & 9 & 3.3 & $13.0 \mathrm{~b}$ & 7.4 \\
\hline $\begin{array}{l}\text { T3- Carboxina; Tiram }{ }^{\circledast}(300 \mathrm{ml})+ \\
\text { Imidacloprido }^{\circledast}(150 \mathrm{ml})\end{array}$ & 16.5 & 3.8 & $38.5 \mathrm{ab}$ & 8.2 & 8.5 & 2.1 & $18.0 \mathrm{ab}$ & 2.8 \\
\hline $\begin{array}{l}\text { T4- Metalaxil-M; Fludioxonil }{ }^{\circledast}(75 \mathrm{ml}) \\
\text { + Piraclosrobina; Tiofanato-metílico; } \\
\text { Fipronil }^{\circledast}(150 \mathrm{ml})\end{array}$ & 11.5 & 4.5 & $36.0 \mathrm{ab}$ & 3.7 & 4 & 0,7 & $19.5 \mathrm{ab}$ & 3.4 \\
\hline $\begin{array}{l}\text { T5- Metalaxil-M; Fludioxonil }{ }^{\circledast}(100 \mathrm{ml}) \\
\text { + Piraclostrobina; Tiofanato-metílico; } \\
\text { Fipronil }^{\circledast}(150 \mathrm{ml})\end{array}$ & 21.5 & 4.5 & $36.0 \mathrm{ab}$ & 7.5 & 7.5 & 4.2 & $17.5 \mathrm{~b}$ & 4.2 \\
\hline $\begin{array}{l}\text { T6- Tiofanato-metílico; Fluazinam }{ }^{\circledR}(145 \\
\text { ml) + Piraclostrobina; Tiofanato-metílico; } \\
\text { Fipronil }^{\circledast}(150 \mathrm{ml})\end{array}$ & 19.5 & 2.2 & $32.5 \mathrm{ab}$ & 8.4 & 8.5 & 2.2 & $18.0 \mathrm{ab}$ & 4.3 \\
\hline $\begin{array}{l}\text { T7- Tiofanato-metílico; Fluazinam }{ }^{\circledR}(180 \\
\text { ml })+ \text { Piraclostrobina; Tiofanato-metílico; } \\
\text { Fipronil }^{\circledast}(150 \mathrm{ml})\end{array}$ & 11.5 & 3.4 & $28.0 \mathrm{~b}$ & 5.2 & 8.5 & 2 & $14.5 \mathrm{~b}$ & 6.0 \\
\hline Coefficient of variation (\%) & 38.7 & & 18.6 & & 48.1 & & 30.5 & \\
\hline
\end{tabular}

replanting procedures, which lead to increased costs, and making it possible to obtain higher yields (Table 4).

\subsection{Evaluation of seed performance in sand}

In the variable first germination count in sand (Table 1) there was no statistical difference by the Tukey test at
$5 \%$ probability of error, however all treatments differed from the control, obtaining a higher germination index in the first count.

In Table 2, the percentage of final emergence in sand, the treatments T2 (Carboxin; Thiram ${ }^{\circledR}(250 \mathrm{ml})+$ Imidacloprid $^{\circledR}(150 \mathrm{ml})$ ) and T3 (Carboxin; Thiram ${ }^{\circledR}(300 \mathrm{ml})$ 
Table 4. Averages of shoot and root lengths ( $\mathrm{cm}$ ) of CA-1512 strain lentil seedlings after emergence in paper and emergence in sand. Santa Maria, 2020.

\begin{tabular}{|c|c|c|c|c|c|c|c|c|}
\hline \multirow{3}{*}{ Treatments } & \multicolumn{4}{|c|}{ Emergence in paper } & \multicolumn{4}{|c|}{ Emergence in sand } \\
\hline & \multicolumn{2}{|c|}{ Root lengths } & \multicolumn{2}{|c|}{ Lengths shoot } & \multicolumn{2}{|c|}{ Root lengths } & \multicolumn{2}{|c|}{ Lengths shoot } \\
\hline & & Sd & & Sd & & Sd & & Sd \\
\hline T1- Control & $3.30 \mathrm{~b}^{*}$ & 1.1 & $1.30 \mathrm{~b}$ & 0.9 & $7.02 \mathrm{ab}$ & 2.2 & $6.79 \mathrm{ab}$ & 3.1 \\
\hline $\begin{array}{l}\text { T2-Carboxina; Tiram }{ }^{\circledast}(250 \mathrm{ml}) \\
\text { + Imidacloprido } \\
(150 \mathrm{ml})\end{array}$ & $3.02 \mathrm{~b}$ & 0.99 & $1.67 \mathrm{~b}$ & 0.67 & $9.18 \mathrm{a}$ & 2.5 & $7.63 \mathrm{ab}$ & 0.75 \\
\hline $\begin{array}{l}\text { T3- Carboxina; Tiram } \\
\text { + }^{\circledR}(300 \mathrm{ml}) \\
\text { Imidacloprido }^{\circledR}(150 \mathrm{ml})\end{array}$ & $3.12 \mathrm{~b}$ & 1.6 & $1.62 \mathrm{~b}$ & 0.34 & $5.71 \mathrm{~b}$ & 0.72 & $6.10 \mathrm{~b}$ & 0.87 \\
\hline $\begin{array}{l}\text { T4- Metalaxil-M; Fludioxonil }{ }^{\circledast} \\
(75 \mathrm{ml})+\text { Piraclostrobina; } \\
\text { Tiofanato-metílico; Fipronil }{ }^{\circledast} \\
(150 \mathrm{ml})\end{array}$ & $2.60 \mathrm{c}$ & 0.78 & $1.27 \mathrm{~b}$ & 0.55 & $7.59 \mathrm{ab}$ & 1.6 & $6.93 \mathrm{ab}$ & 1 \\
\hline $\begin{array}{l}\text { T5- Metalaxil-M; Fludioxonil }{ }^{\circledR} \\
(100 \mathrm{ml})+\text { Piraclostrobina; } \\
\text { Tiofanato-metílico; Fipronil } \\
(150 \mathrm{ml})\end{array}$ & $2.25 \mathrm{c}$ & 1.4 & $1.55 \mathrm{~b}$ & 0.56 & $7.01 \mathrm{ab}$ & 1.7 & $8.16 \mathrm{a}$ & 0.99 \\
\hline $\begin{array}{l}\text { T6- Tiofanato-metílico; } \\
\text { Fluazinam }{ }^{\circledR}(145 \mathrm{ml})+ \\
\text { Piraclostrobina; Tiofanato- } \\
\text { metílico; Fipronil }{ }^{\circledast}(150 \mathrm{ml})\end{array}$ & $2.72 \mathrm{c}$ & 1.3 & $1.42 \mathrm{~b}$ & 0.3 & $6.91 \mathrm{ab}$ & 0.98 & $7.80 \mathrm{ab}$ & 2.1 \\
\hline $\begin{array}{l}\text { T7- Tiofanato-metílico; } \\
\text { Fluazinam }{ }^{\circledast}(180 \mathrm{ml})+ \\
\text { Piraclostrobina; Tiofanato- } \\
\text { metílico; Fipronil }{ }^{\circledast}(150 \mathrm{ml})\end{array}$ & $4.0 \mathrm{a}$ & 0.9 & $2.02 \mathrm{a}$ & 0.82 & $6.05 \mathrm{~b}$ & 1 & $7.11 \mathrm{ab}$ & 0.88 \\
\hline Coefficient of variation (\%) & 14.4 & & 14.1 & & 17.9 & & 11.06 & \\
\hline
\end{tabular}

${ }^{*}$ Means not followed by the same letter in the column were statistically different between cultivars in the Tukey test ( $\left.\mathrm{p} \leq 0.05\right)$; Sd: Standard deviation.

+ Imidacloprid $\left.^{\circledR}(150 \mathrm{ml})\right)$ with averages of 72,50 and $56,25 \%$, respectively, obtained values lower than acceptable by the legislation (80\%). Possibly, both treatments caused phytotoxicity in lentil seeds, negatively interfering in their percentage of emergence.

For the variables length of aerial part and radicle in sand, the worst treatment was T3 (Carboxine; Tiram ${ }^{\circledR}$ $(300 \mathrm{ml})+$ Imidacloprido $\left.{ }^{\circledR}(150 \mathrm{ml})\right)$, because it obtained the lowest averages for the length of aerial part and radicle in sand (Table 4).

\section{Discussion}

Significant statistical differences show that seed treatment with fungicides and insecticides has shown satisfactory results in the physiological quality of the seeds, as affirmed by Almeida et al. (2014). For the variable first germination count on paper, Cunha et al. (2015) highlighted that the treatment of soybean seeds with Metalaxyl-M; Fludioxonil and Pyraclostrobin; Thiophanate-methyl; Fipronil, maintained their physiological, genetic and sanitary quality, promoting beneficial effects in several stages of the initial growth, as seen in Table 1 for T4.

In the first sand count (Table 1 ), the results obtained were similar results were verified by Menten and Moraes (2010) and Trafane (2014), who found low percentage of germination of soybean seeds without treatment, compared to treated seeds. T3 had the worst index, corroborating with the study conducted by Barbosa et al. (2017), who used Imidacloprid products, in combination and individually, in the treatment of corn seeds and observed a lower percentage of seedling emergence compared to the other treatments.

In the percentage of final emergence in sand (Table 2), the treatments T4 and T7, even not being indicated for lentil crop, proved to be beneficial in seed treatment, being a viable alternative for the crop, improving the physiological quality of its seeds, by increasing their germination percentage. In contrast to the results found in the present study, Pereira et al. (2009) and Grisi et al. (2009) observed in soybean and sunflower that the treatment of seeds with different fungicides and insecticides including Metalaxyl-M; Fludioxonil $^{\circledR}$ and Pyraclostrobin; Thiophanate-methyl; Fipronil ${ }^{\circledR}$ did not interfere in the emergence of seedlings.

Knowledge of the effect of treatments on the formation of normal seedlings is of great importance, since there is a relationship between leaf area and photosynthetic activity, consequently promoting greater plant development (Oliveira et al., 2009; Sousa et al., 2015).

The T6 (Table 3) presented greater radicle lengths and part area, this result corroborates those found by Frare (2019) in a study with soybean seed treatment, in which the fungicide based on Thiophanate-methyl + Fluazinam 
and insecticide based on Fipronil resulted in greater root length compared to the other treatments.

\section{Conclusions}

Seed treatment T7 (Thiophanate-methyl; Fluazinam ${ }^{\circledR}$ $(180 \mathrm{ml})+$ Pyraclostrobin; Thiophanate-methyl; Fipronil ${ }^{\circledR}$ $(150 \mathrm{ml}))$ promoted higher levels of germination under accelerated aging, lower number of abnormal seedlings and longer lengths of shoot and radicle for the emergence in paper.

The treatment T2 (Carboxin; Thiram ${ }^{\circledR}(250 \mathrm{ml})+$ Imidacloprid $^{\circledR}(150 \mathrm{ml})$ ) allowed a higher index in the first count of germination in sand, lower number of dead seeds under accelerated aging and longer root length, in the emergence in sand. Shoot length, in the emergence in sand, increased under seed treatment with T4 (Metalaxyl-M; Fludioxonil $^{\circledR}(75 \mathrm{ml})+$ Pyraclostrobin; Thiophanate-methyl; Fipronil $\left.^{\circledR}(150 \mathrm{ml})\right)$.

The treatments with fungicides and insecticides, used in this experiment, have improved considerably as physiological properties of the seeds, and can be a reliable option for the cultivation of lentils, because in addition to guaranteeing the quality of the seed, it will provide an adequate and safe development in the field.

\section{References}

ALMEIDA, A.S., CASTELLANOS, C.I.S., DEUNER, C., BORGES, C.T. and MENEGHELLO, G.E., 2014. Efeitos de inseticidas, fungicidas e biorreguladores na qualidade fisiológica de sementes de soja durante o armazenamento. Revista de Agricultura (Piracicaba), vol. 89, no. 3, pp. 172-182. http://dx.doi.org/10.37856/bja. v89i3.173.

AMARO, H.T.R., DAVIS, A.M.S.S., ASSIS, M.O., RODRIGUES, B.R.A., CANGUSSÚ, L.V.S. and OLIVEIRA, M.B., 2015. Testes de vigor para avaliação da qualidade fisiológica de sementes de feijoeiro. Revista de Ciências Agrárias (Belém), vol. 38, no. 3, pp. 383-389.

BALARDIN, R.S., SILVA, F.D.L., DEBONA, D., DALLA CORTE, G., DALLA FAVERA, D. and TORMEN, N.R., 2011. Tratamento de sementes com fungicidas e inseticidas como redutores dos efeitos do estresse hídrico em plantas de soja. Ciência Rural, vol. 41, no. 7, pp. 1120-1126. http://dx.doi.org/10.1590/S010384782011000700002.

BARBOSA, R. G., RADKE, A. K. and MENEGHELLO, G. D., 2017. Inseticidas no tratamento de sementes: reflexos nos estádios de desenvolvimento inicial de plantas de soja. Revista da $14^{\mathrm{a}}$ Jornada de Pós-Graduação e Pesquisa, pp. 1-8.

BRASIL, 2003. Lei $n^{0} 10.711$, de 5 de agosto de 2003. Dispõe sobre o Sistema Nacional de Sementes e Mudas e dá outras providências. Diário Oficial da República Federativa do Brasil, Brasília.

BRASIL, 2009. Regras para análise de sementes. Brasília, DF: Ministério da Agricultura, Pecuária e Abastecimento, Secretaria de Defesa Agropecuária, 395 p.

BEM, L. D., FERRARI, J. L., DARIO, G. and RAETANO, C. G., 2020. Impact of storage on the physiological quality of soybean seeds after treatment with fungicides and insecticides. Journal of Seed Science, vol. 42, pp. e202042037.
CARVALHO, N. M. and NAKAGAWA, J., 2012. Sementes: ciência, tecnologia e produção. 5. ed. Jaboticabal: FUNEP, pp. 331.

CORREA, I.N. and POLTRONIERI, F., 2016. Hypocholesterolemic action of proteins from legumes. Revista da Associação Brasileira de Nutrição, vol. 7527, no. 2, pp. 79-90.

CUNHA, R.P., CORRÊA, M.F., SCHUCH, L.O.B., OLIVEIRA, R.C., ABREU JUNIOR, J.S., SILVA, J.D.G. and ALMEIDA, T.L., 2015. Diferentes tratamentos de sementes sobre o desenvolvimento de plantas de soja. Ciência Rural, vol. 45, no. 10, pp. 1761-1767. http:// dx.doi.org/10.1590/0103-8478cr20140742.

DAN, L. G. M., DAN, H. A., BARROSO, A. L. L., and BRACCINI, A. L., 2010. Qualidade fisiológica de sementes de soja tratadas com inseticidas sob efeito do armazenamento. Revista Brasileira de Sementes, vol. 32, no. 2, pp. 131-139. https://doi.org/10.1590/ S0101-31222010000200016.

EMPRESA BRASILEIRA DE PESQUISA AGROPECUÁRIA - EMBRAPA, 2018 [viewed 4 March 2020]. Diálogos estratégicos [online]. Brasília, DF: EMBRAPA. Available from: https://www. alice.cnptia.embrapa.br/alice/bitstream/doc/1096615/1/ PulsesProducaoConsumonaIndia.pdf

FAOSTAT, 2020 [viewed 4 August 2020]. Crops, produção de lentilhas no mundo [online]. Rome: Food and Agriculture Organization of the United Nations. Available from: http://www.fao.org/ faostat/en/\#data/QC/visualize

FERREIRA, D.F., 2011. Sisvar: a computer statistical analysis system. Ciência e Agrotecnologia, vol. 35, no. 6, pp. 1039-1042. http:// dx.doi.org/10.1590/S1413-70542011000600001.

FRARE, A.T., 2019. Desempenho de sementes de soja (Glycine max) tratadas com fungicida isolado e combinado à inseticida $e$ fertilizante. Trabalho de Conclusão de Curso, Uberlândia - MG.

GRISI, P.U., SANTOS, C.M., FERNANDES, J.J. and SÁ JÚNIOR, A., 2009. Qualidade das sementes de girassol tratadas com inseticidas e fungicidas. Bioscience Journal, Uberlândia, vol. 25, no. 4, pp. 28-36. http://dx.doi.org/10.1590/S0101-31222010000200016.

Instituto Brasileiro de Geografia E Estatística - IBGE, 2019 [viewed 11 December 2020]. Censo Agropecuário. Available from: https:// www.ibge.gov.br/busca.html?searchword=cidades\%20mais\%20 arborizadas\&start $=1760$

JOHNSON, C.R., THAVARAJAH, D., COMBS, J.R., GERALD, F. and THAVARAJAH, P., 2013. Lentil (Lens culinaris L.): a prebiotic-rich whole food legume. Food Research International, vol. 51, no. 1, pp. 107-113. http://dx.doi.org/10.1016/j.foodres.2012.11.025.

KRZYZANOWSKI, F.C., HENNING, A.A., HENNING, F.A., FRANÇANETO, J.B. and LORINI, I., 2014. Influência do volume de calda e da combinação de produtos usados no tratamento da semente de soja sobre o seu desempenho fisiológico. In: Anais da $34^{\circ}$ Reunião de Pesquisa de Soja, 2014, Londrina. Londrina: EMBRAPA, pp. 222-225.

LEMES, E., ALMEIDA, A., JAUER, A., MATTOS, F. and TUNES, L., 2019. Tratamento de sementes industrial: potencial de armazenamento de sementes de soja tratadas. Colloquium Agrariae, vol. 15, no. 3, pp. 94-103. http://dx.doi.org/10.5747/ ca.2019.v15.n3.a302.

MARCOS FILHO, J., 1999.Teste de envelhecimento Acelerado. In: F.C. KRZYZANOWSKI, R.D. VIEIRA and J.B. FRANÇANETO, eds. Vigor de sementes: conceitos e testes. Londrina: ABRATES, cap. 3, pp. 1-24.

MENTEN, J.O. and MORAES, M.H.D., 2010. Tratamento de sementes: histórico, tipos, características e benefícios. Informativo ABRATES, vol. 20, no. 3, pp. 52 . 
NASCIMENTO, W.M., VIEIRA, R.F. and LIMA, R.R., 2016. Lentilha. In: W.M. NASCIMENTO, ed. Hortaliças leguminosas. Brasília: EMBRAPA, vol. 1, pp. 121-146.

OLIVEIRA, F.A., OLIVEIRA FILHO, A.F., MEDEIROS, J.F., ALMEIDA JÚNIOR, A.B. and LINHARES, P.C.F., 2009. Desenvolvimento inicial da mamoneira sob diferentes fontes e doses de matéria orgânica. Revista Caatinga, vol. 22, no. 1, pp. 206-211.

PEREIRA, C.E., OLIVEIRA, J.A., OLIVEIRA, G.E., ROSA, M.C.M. and NETO, J.C., 2009. Tratamento fungicida via peliculização e inoculação de Bradyrhizobium em sementes de soja. Revista de Ciências Agronômicas, Fortaleza, vol. 40, no. 3, pp. 433-440.

SILVA, N.D., 2016. Substratos e metodologia alternativa para o teste de germinação em sementes de soja tratadas quimicamente.
Pelotas: Faculdade de Agronomia Eliseu Maciel, Universidade Federal de Pelotas, 55 p. Dissertação de Mestrado em Ciência e Tecnologia de Sementes.

SOUSA, G.C., RIBEIRO, A.A., MENEZES, A.S., MOREIRA, F.J. and CUNHA, C.S.M., 2015. Emergência e crescimento inicial de sorgo (Sorghum bicolor L.) em diferentes substratos. Agropecuária Científica no Semiárido, vol. 11, no. 4, pp. 63-71.

TRAFANE, L.G., 2014. Tratamento industrial de sementes de soja e seus reflexos na qualidade durante o período de armazenamento. Pelotas: Faculdade de Agronomia Eliseu Maciel, Universidade Federal de Pelotas, 38 p. Dissertação de Mestrado em Ciência e Tecnologia de Sementes. 